\title{
Dual stresses of flooding and agricultural land use reduce earthworm populations more than the individual stressors
}

Article

Accepted Version

Creative Commons: Attribution-Noncommercial-No Derivative Works 4.0

Kiss, T. B. W., Chen, X., Ponting, J., Sizmur, T. ORCID: https://orcid.org/0000-0001-9835-7195 and Hodson, M. E. (2021) Dual stresses of flooding and agricultural land use reduce earthworm populations more than the individual stressors. Science of The Total Environment, 754. 142102. ISSN 0048-9697 doi:

https://doi.org/10.1016/j.scitotenv.2020.142102 Available at https://centaur.reading.ac.uk/92668/

It is advisable to refer to the publisher's version if you intend to cite from the work. See Guidance on citing.

Published version at: https://doi.org/10.1016/j.scitotenv.2020.142102

To link to this article DOI: http://dx.doi.org/10.1016/j.scitotenv.2020.142102

Publisher: Elsevier

All outputs in CentAUR are protected by Intellectual Property Rights law, including copyright law. Copyright and IPR is retained by the creators or other copyright holders. Terms and conditions for use of this material are defined in the End User Agreement. 


\section{CentAUR}

Central Archive at the University of Reading

Reading's research outputs online 
Contact email for the corresponding author: Tamsyn.Kiss@gmail.com addresses: Tamsyn.Kiss@gmail.com, Mark.Hodson@york.ac.uk

b. University of Leeds, Leeds, United Kingdom, LS2 9JT. Author email address: X.Chen@leeds.ac.uk RG6 6AH. Author email addresses: Jessica.Ponting@pgr.reading.ac.uk, T.Sizmur@reading.ac.uk

Corresponding author: Tamsyn Kiss

\section{Dual stresses of flooding and agricultural land use reduce earthworm populations more than the individual stressors}

Tamsyn B.W. Kiss ${ }^{\mathrm{a}}$, Xiaohui Chen ${ }^{\mathrm{b}}$, Jessica Ponting ${ }^{\mathrm{c}}$, Tom Sizmur ${ }^{\mathrm{c}}$, Mark E. Hodson ${ }^{\text {a }}$

a. University of York, Heslington, York, United Kingdom, YO10 5DD. Author email

c. University of Reading, Whiteknights, PO Box 217, Reading, Berkshire, United Kingdom,

4 


\section{Abstract}

16 Global climate change is leading to a significant increase in flooding events in many countries. Current 17 practices to prevent damage to downstream urban areas include allowing the flooding of upstream agricultural land. Earthworms are ecosystem engineers, but their abundances in arable land are already reduced due to pressure from farming practices. If flooding increases on agricultural land, it is important to understand how earthworms will respond to the dual stresses of flooding and agricultural land use. The earthworm populations under three land uses (pasture, field margin, and crops), across two UK fields, were sampled seasonally over an 18-month period in areas of the fields which flood frequently and areas which flood only rarely. Earthworm abundance in the crop and pasture soils and total earthworm biomass in the crop soils was significantly lower in the frequently flooded areas than in the rarely flooded areas. The relative percentage difference in the populations between the rarely and frequently flooded areas was greater in the crop soils (-59.18\% abundance, $-63.49 \%$ biomass) than the pasture soils $(-13.39 \%$ abundance, $-9.66 \%$ biomass $)$. In the margin soils, earthworm abundance was significantly greater in the frequently flooded areas $(+140.56 \%)$, likely due to higher soil organic matter content and lower bulk density resulting in soil conditions more amenable to earthworms. The findings of this study show that earthworm populations already stressed by the activities associated with arable land use are more susceptible to flooding than populations in pasture fields, suggesting that arable earthworm populations are likely to be increasingly at risk with increased flooding.

\section{Highlights}

- We surveyed earthworms in frequently and rarely flooded areas of UK fields

- Flooding increased soil organic matter and reduced soil bulk density

- Earthworm abundance in regularly flooded soils was lower than in rarely flooded soils

- Populations decreased due to flooding relatively more in crop than pasture soils

- Earthworm populations in arable soils are susceptible to future flooding 

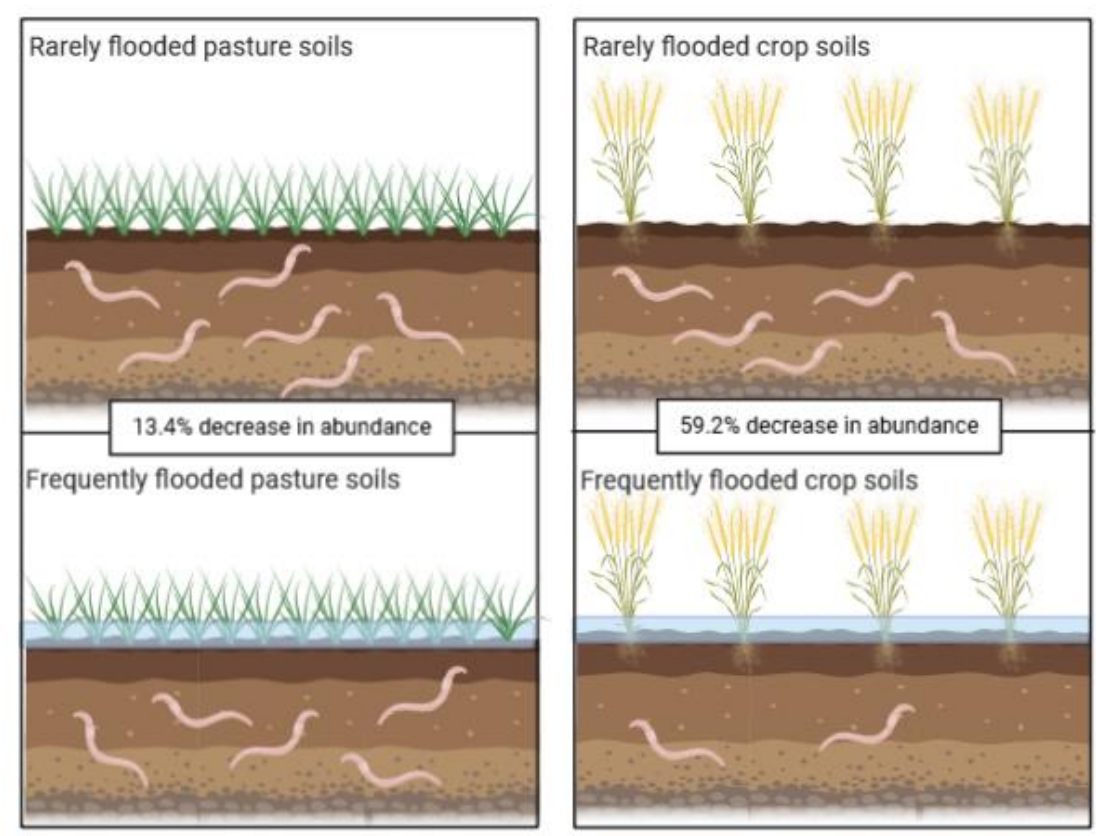

42 Keywords

43 Flooding, land use, earthworms, climate change, population dynamics

\section{1. Introduction}

The global climate is changing, leading to changes in rainfall frequency and flooding regimes across the world (Kundzewicz et al., 2014; Hirabayashi and Kanae, 2009), including in the temperate regions of Europe (Bronstert, 2003; Blöschl et al., 2017). Models predict an increase in flood discharge rates of 10-30\% from many rivers globally over the next century (Hirabayashi et al., 2013). In the UK, flooding events associated with increased rainfall have been increasing in both frequency and intensity, with the mean annual floodwater discharge in the UK increasing by approximately 12\% between 1960 and 2010 (Prudhomme et al., 2003). While these events can cause catastrophic damage to urban conurbations they also affect arable and pasture fields, leading not only to losses of crops and livestock but also to reductions in crop viability and loss of grassland for grazing (ADAS, 2014). With the threat of flooding

54 increasing on agricultural land, due to climatic changes, land use changes, and land management 
changes, and the flooding of farmland to prevent damage of downstream urban areas (Lane, 2017), the question that arises is; what impact will these flooding events have on soil fauna?

Earthworms are important soil fauna. They are a key food source for many animals such as badgers (Skinner and Skinner, 1988), foxes (Macdonald, 1980), birds (Ausden et al., 2001; Wilson et al., 1999) and moles (Funmilayo, 1979). Perhaps more importantly, earthworms are also 'ecosystem engineers' (Jones et al., 1994); organisms which "directly or indirectly modulate the availability of resources to other species, by causing physical state changes in biotic or abiotic materials" (Lawton, 1994). Earthworms fulfil this role in the soil environment by their behaviours and activities (e.g. movement, consumption, and excretion). Their tunnelling increases soil porosity (Stork and Eggleton, 1992) and soil water infiltration rates (Ernst et al., 2009; Hallam et al., 2020), including in floodplain soils (Schütz et al., 2008). The consumption of soil and organic matter by earthworms contributes to the nutrient turnover of the soil, either through excretion of casts that contain greater macro- and micronutrient availability than the ingested material (Barley and Jennings, 1959; Whalen and Parmelee, 1999; Tomati and Galli, 1995; Sizmur and Hodson, 2009; Sizmur and Richardson, 2020), or through the release of nutrients from earthworm tissues after death (Syers and Springett, 1984). Casting of digested material increases the aggregate stability of the soil (Zhang and Schrader, 1992; Maeder et al., 2002; Hallam and Hodson, 2020) and bioturbates organic matter (Scheu, 1987; Meysman et al., 2006). These activities result in improved plant growth in the presence of earthworms (Tomati et al., 1988; Scheu et al., 1999; van Groenigen et al., 2014; Hallam et al., 2020). For example, earthworms increase crop yield by up to $25 \%$ when soil nitrogen is limited (van Groenigen et al., 2014).

Given that the actions of earthworms in soil give rise to many of the ecosystem services that soils deliver (Blouin et al., 2013), it is important to consider whether changes in flooding regimes with changing climatic conditions and flood management will impact earthworm populations, and the further implications this may have on crop yields or grassland production. Within arable soils, the role of earthworms is particularly important given the boost that earthworms provide for crop growth (van Groenigen et al., 2014; Bertrand et al., 2015). However, in arable soils, earthworm populations are greatly reduced in comparison to pasture soils (Curry et al., 2002; Boag et al., 1997; Holden et al., 2019) 
due to a number of factors including crush or cutting damage from agricultural machinery (Boström, 1995; Tomlin and Miller, 1988), the use of pesticides (Pelosi et al., 2013; Ball et al., 1986) and low organic matter contents resulting in insufficient food to sustain large earthworm populations (Reeleder et al., 2006).

It has long been observed that earthworms emerge from the soil after heavy rainfall (Darwin, 1881). The precise reason for this remains unknown, but over repeated flooding events this may lead to reductions in earthworm populations, as earthworms on the soil surface are vulnerable to predation (Tomlin and Miller, 1988). There may also be effects on the earthworm community structure with regular flooding; studies have found that cocoons remain viable following flooding events (Plum and Filser, 2005), but if all adults are removed from the population during a flooding event it will take time for a population to become reproductively viable again. Within the soil itself, inundation may cause physical and chemical changes that create an environment that is either unsuitable for earthworms, such as reduced oxygen concentrations (Ponnamperuma, 1984; Kiss, 2019), or which favours one particular ecotype or behavioural subtype over another. Flooding can lead to increases in the organic matter content of soil through deposition of organic-rich sediment sourced from upstream (Johnston et al., 1984; Venterink et al., 2009) and/or reduced rates of organic matter decay due to reduced oxygen concentrations (Reddy and Patrick Jr, 1975). This increase in organic matter leads to decreases in bulk density (Bronick and Lal, 2005), and increases in soil water holding capacity (Carter, 2002; Rawls et al., 2003), which can lead to higher soil moisture contents. Earthworm population fluctuations in flooded soils, therefore, may depend on a number of factors such as how likely earthworms are to survive flooding events and repopulate the flooded regions; how suitable soil conditions in these flooded areas are for supporting earthworm populations; how viable earthworm cocoons and juveniles remain during and after a flood event; whether earthworm species belonging to different ecotypes respond differently to flooding and rates of earthworm migration after flooding from areas that were not flooded. While some studies have found that earthworm populations in agricultural soils in temperate regions 
respond to flooding events of greater frequency and duration, as expected in some global regions with

109 climate change (Hirabayashi et al., 2013), is less well understood.

110 It is clear from the existing literature that both flooding and agricultural soil use effect earthworm

111 populations. However, studies tend to examine these factors in isolation, which is not necessarily 112 representative of how stressors may accumulate or act in the environment. There are very few studies 113 at the time of writing that have examined how combinations of stressors impact earthworm populations 114 in soil, and none of which we are aware that examine the combined stressors of conventional arable 115 farming and flooding. This study aims to understand the effects that flooding has on the soil 116 environment and on earthworm populations under two very different land uses. To achieve this, one 117 pasture field and one arable field (containing soils used for growing crops and soils from the field 118 margin), each with frequently flooded and rarely flooded areas in the same field, were visited on a 119 number of occasions between 2016 and 2018. Soil properties and earthworm populations were measured in the pasture, margin, and crop soils to represent a spectrum of low, medium, and high levels 121 of soil disturbance, in areas known to flood more frequently and areas known to flood rarely. Three broad hypotheses were considered:

1. Soil properties differ based both on the frequency of flood events and the land use, with higher soil bulk density, and lower soil moisture, $\mathrm{pH}$, percent carbon and percent nitrogen in the arable soils and the rarely flooded regions than in the pasture soils or the frequently flooded soils.

2. Earthworm abundance and biomass will be lower in the frequently flooded soils and the crop soils than in the rarely flooded soils or the pasture soils. differently. 


\section{Methods}

\section{$131 \quad$ 2.1. Field sites}

132 Two field sites were used for this study. A pasture field located at British National Grid (BNG) reference

133 SU 7515368746 near Reading, England, and an arable field located at BNG reference SE 3620081600

134 near Holme-On-Swale in Yorkshire, England. Both of these fields border rivers: the river Loddon

135 borders the pasture field, and the river Swale the arable field (Figure 1) Communication with land

136 managers confirmed that at both sites there are areas of the field subject to frequent flooding and areas

137 of the field which rarely flood, due to both distance from the river and the topography of the field though

138 precise records of the date and duration of individual flood events were not available. As groundwater

139 level data were only available for the frequently flooded pasture soils we were unable to use this data

140 in our analysis of controls on earthworm distributions across the different sampling sites within the

141 same field and between fields. Due to this reason, it is not possible to attribute flooding events

142 specifically to groundwater or riverine flooding. 


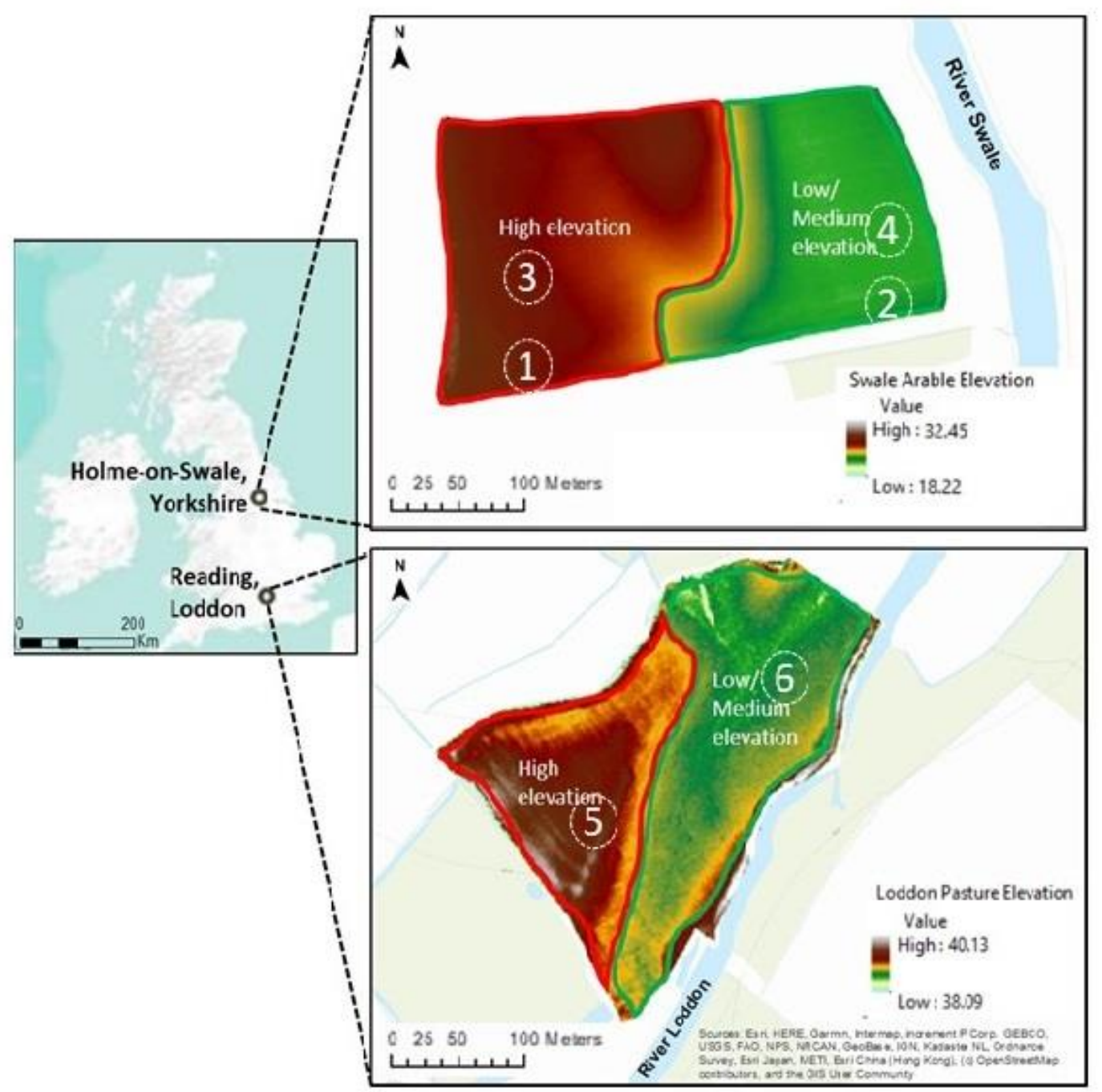

144 Figure 1 - The location of the Loddon pasture field near Reading, England, and the Swale arable field near Holme-On-Swale, England and LIDAR graphs representing the topography of the fields. Samples for the rarely flooded areas (sites 1, 3 and 5) were taken from areas of high elevation (coloured brown, on the western side of the fields). Samples for the frequently flooding areas (sites 2, 4 and 6) were taken from areas of low and medium elevation (coloured green, on the eastern side of the fields). In the arable field sites 1 and 2 were located in the field margin soil and sites 3 and 4 in the arable soil.

The pasture field was visited every three months over a period of eighteen months, from November 1522016 to February 2018. On each visit, six randomly positioned samples were taken from the rarely 153 flooded area and twelve from the frequently flooded area. A higher number of samples were taken in 
the frequently flooded area as, according to the land manager, there appeared to be two distinct drainage rates within this area. However, we have combined all the data from the frequently flooded area because our focus is the comparison of frequently and rarely flooded soils. In addition, preliminary data analysis (not reported here) indicated that, when present, any differences in soil properties and earthworm populations in the frequently flooded area between the areas with apparently different drainage rates were minor and rarely significant. Combining the data results in a greater number of frequently flooded than rarely flooded soil samples for the pasture field. The arable field was visited approximately every three months, from April 2017 to January 2018. The decision to only sample for one year was due to the generally low earthworm abundances at this site. On each visit, six randomly positioned samples were taken in each of four locations: a crop soil and a field margin soil, from both the frequently flooded and rarely flooded areas.

\subsection{Earthworm and soil sampling}

Samples were taken by excavating a pit measuring $20 \mathrm{~cm} \times 20 \mathrm{~cm} \times 20 \mathrm{~cm}$. The soil was extracted using a sharp levering motion with a spade and put into a high sided tray in order to prevent earthworm escape. The extracted soil was hand-sorted for live earthworms. Any earthworms living deeper within the soil were expelled using one litre of $0.13 \mathrm{ml} \mathrm{L}^{-1}$ concentration allyl isothiocyanate in deionised water (Zaborski, 2003; Pelosi et al., 2009), which was poured into the pit and left for 30 minutes to drain into the soil. The combination of hand-sorting soil and use of a chemical expellant is the most effective method of sampling the earthworm community (Pelosi et al., 2009). Emerging earthworms were rinsed with deionised water and stored separately from earthworms collected from the pit. Earthworms were collected live and transported back to the laboratory in moist soil. The soil temperature at $5 \mathrm{~cm}$ and 10 $\mathrm{cm}$ depths for each pit was recorded by inserting a soil temperature probe horizontally into the intact soil adjacent to the pit. A soil sample was collected by hammering a bulk density ring of volume 63.62 $\mathrm{cm}^{3}$ (height $4 \mathrm{~cm}$, diameter $5.5 \mathrm{~cm}$ ) into the side of the freshly dug pit, approximately $10 \mathrm{~cm}$ below the soil surface. The sample was brought back to the laboratory for analysis of soil moisture content, bulk density, soil pH, and soil carbon and nitrogen content. 
In the laboratory, live adult earthworms were identified using the OPAL "Key to Common British

181 Earthworms" (Jones and Lowe, 2016) and weighed. Juvenile and adult earthworms, earthworm

182 fragments or dead earthworms were recorded as such and weighed.

\subsection{Soil analysis}

Soil samples collected in the bulk density ring were dried at $105^{\circ} \mathrm{C}$ for 24 hours with pre- and postdrying weights used to calculate gravimetric moisture content and oven-dried soil bulk density. Soil pH was determined by adding $40 \mathrm{ml}$ of deionised water to $10 \mathrm{~g}$ of the dried soil sample in $50 \mathrm{ml}$ polypropylene tubes, which were shaken for two hours and left to stand for one hour in order to allow any particulate matter to settle. Soil $\mathrm{pH}$ readings were taken using a Thermo Orion 420A plus $\mathrm{pH} / \mathrm{ISE}$ Meter, calibrated with $\mathrm{pH}$ 4, $\mathrm{pH} 7$ and $\mathrm{pH} 10$ buffers. Soil texture was determined by hand texturing (Thien, 1979).

Total soil carbon and nitrogen were determined using a Vario Macro $\mathrm{C} / \mathrm{N}$ analyser. A subsample of the oven-dried soil was finely ground in a ball mill and approximately $100 \mathrm{mg} \pm 5 \mathrm{mg}$ were analysed to determine soil $\% \mathrm{C}$ and $\% \mathrm{~N}$ content. The $\mathrm{C} / \mathrm{N}$ analyser was calibrated using samples of glutamic acid of the same mass as the soil. A certified organic analytical standard of Peaty soil from Elemental Microanalysis Ltd (B2176 - batch 133519) gave recoveries of $97 \%(\operatorname{std} \operatorname{dev}=2.21 \%, \mathrm{n}=5$ ) and $100 \%$ ( std dev $=2.94 \%, \mathrm{n}=5$ ) for certified concentrations of $15.95 \% \mathrm{C}$ and $1.29 \% \mathrm{~N}$, respectively.

\subsection{Data analysis and statistical methods}

Our entire raw data set is provided in the SI. Data were analysed using RStudio (R Core Team, 2019). The soil properties used in further analysis were: soil bulk density $\left(\mathrm{g} \mathrm{cm}^{-3}\right)$, soil moisture content $(\%)$, soil $\mathrm{pH}$, soil carbon content (\%), and soil nitrogen content (\%). For the statistical analysis, soil $\mathrm{pH}$ was converted to $\mathrm{H}^{+}$activity. Prior to statistical testing, all datasets for soil properties and earthworm populations were tested for normality and heteroscedasticity and, where appropriate, transformed, or non-parametric statistical tests used. The total abundance of earthworms which had been extracted from the pit through both hand sorting and allyl isothiocyanate expulsion was calculated for each pit and expressed on a $\mathrm{m}^{-2}$ basis. Partial earthworms were not included in this calculation. Total biomass of 
earthworms $\left(\mathrm{g} \mathrm{m}^{-2}\right)$ was the sum of the biomass of each individual, including partial earthworm body

207 fragments. The percentage of the total abundance represented by juveniles was calculated, and for analysis arcsine transformed.

The data were categorised by both the flooding regime and the land use. Two categories were established for the frequency of flooding: rarely flooded and frequently flooded. Three categories were established for land use: crop and margin soils from the arable field, and pasture soils from the pasture field. To address the hypotheses established for this paper, the data were analysed using linear mixed effect (LME) models, treating the sampling date as a random effect and treating the land use and flooding regime as fixed effects for each soil property or population factor measure. For soil $\mathrm{pH}$, soil percentage carbon, and total earthworm abundance, the linear mixed effect models were overfitted and so generalised linear models were instead used to compare the effects of flooding and land use on these factors. Tukey post hoc testing was then performed to determine where differences occurred between flooding and land uses. As samples were collected year-round, with sampling date used as a random factor, the effect of land use and flooding are representative of the populations in general, and therefore not sensitive to the timing of an individual flooding event. Finally, the relative percentage difference in earthworm abundance and earthworm biomass between the rarely and frequently flooded sites were determined for each land use. The means of earthworm abundance and biomass across all pits for each combination of land use and sampling date were used for these calculations with a negative value indicating a decrease from the rarely to the frequently flooded soil. A Kruskal-Wallis test, with post hoc testing performed using a Wilcoxon signed ranks test, was used to determine whether these differences were significantly different between land uses and flooding regimes.

To determine whether the abundance of different earthworm species varied with flooding and land use, the abundance of each earthworm species was calculated. The only species present at a sufficiently high abundance deemed suitable for statistical analysis were Aporrectodea caligionsa $(\mathrm{n}=131$ across the entire data set) and Allolobophora chlorotica $(\mathrm{n}=341$ across the entire data set). The abundances of

231 the other species can be found in Table SI-1. The abundances of these species were expressed as 232 individuals $\mathrm{m}^{-2}$ and cube root transformed to achieve a normal distribution. The effect of flooding and 
land use on the abundances of these two species were determined through the use of LME models,

234 treating the sampling date as a random effect. Tukey post hoc testing was then performed to determine

235 where differences occurred between flooding frequency and land use. The process was repeated to

236 determine how the combined biomass of all individuals of the two species varied with flooding

237 frequency and land use; the biomasses of A. chlorotica were cube root transformed, but no

238 transformation was required for A. caliginosa.

\section{3. Results}

\section{$240 \quad 3.1 . \quad$ Soil properties across different land uses and flooding frequencies}

241 The pasture soils were sandy clay loams and the arable soils were silty clay loams. For all soil properties

242 (bulk density, soil moisture, soil $\mathrm{pH}$, and soil percent carbon and percent nitrogen), there was a significant interaction between flooding and land use on the variation observed in the data $(P<0.001$; Figure 2).

The soils from frequently flooded areas had lower bulk densities than the rarely flooded areas. Soil bulk density was significantly lower in the pasture soils than in the crop and margin soils and frequent flooding resulted in the bulk density of crop and margin soils becoming similar. Soil moisture and soil carbon content were both higher in the soils from frequently flooded areas. As with bulk density, frequent flooding resulted in the crop and margin soil moisture and carbon values becoming more similar. Soil nitrogen content was only higher in the frequently flooded pasture soils, with no significant difference in nitrogen content observed between the rarely and frequently flooded areas for either the crop or margin soils. Only margin soil $\mathrm{pH}$ showed a significant response to flooding, with the $\mathrm{pH}$ in the frequently flooded margin soils significantly greater than the rarely flooded margin soils, to the extent that their $\mathrm{pH}$ was similar (not significantly different) to either crop or pasture soils. 

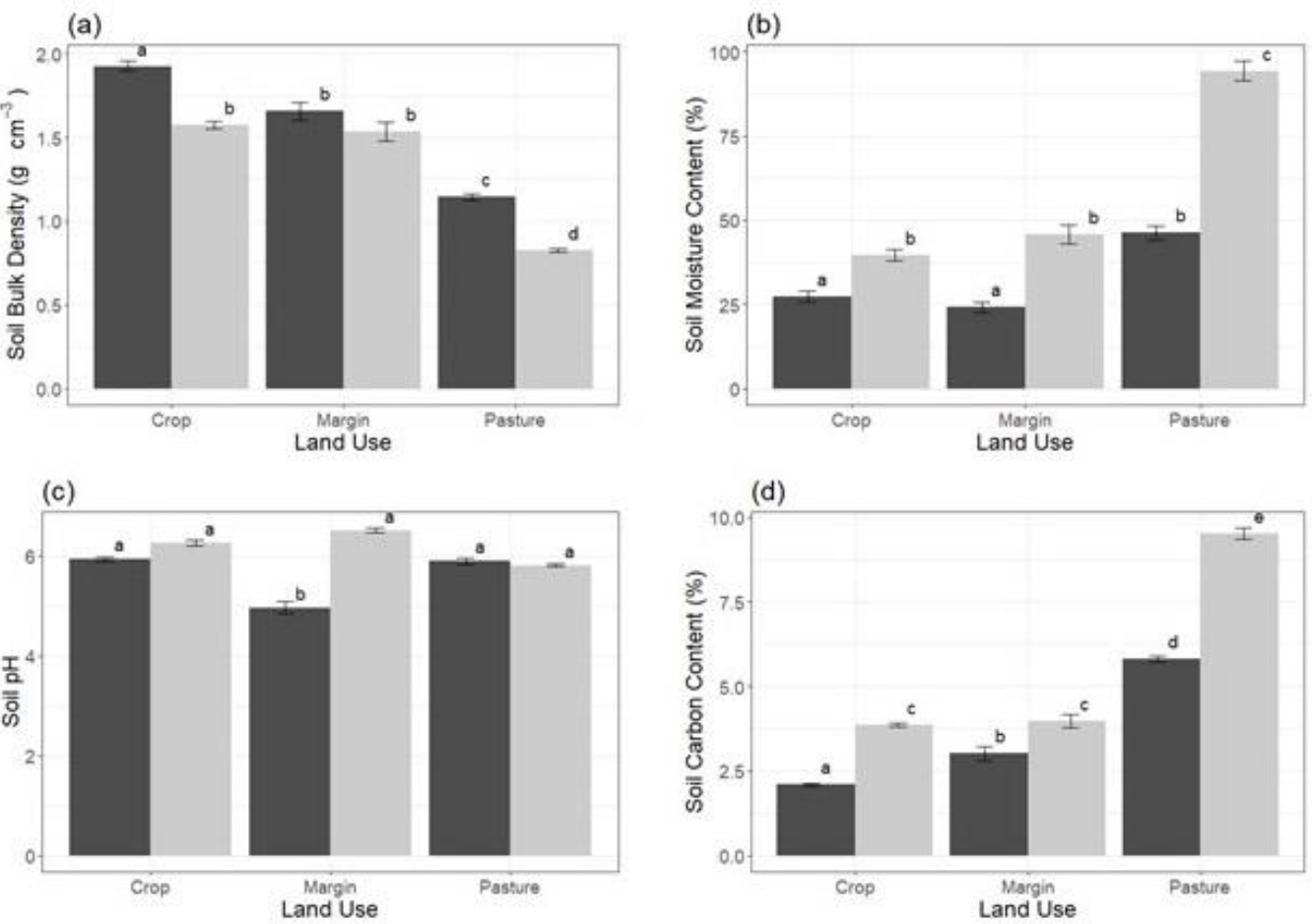

(e)

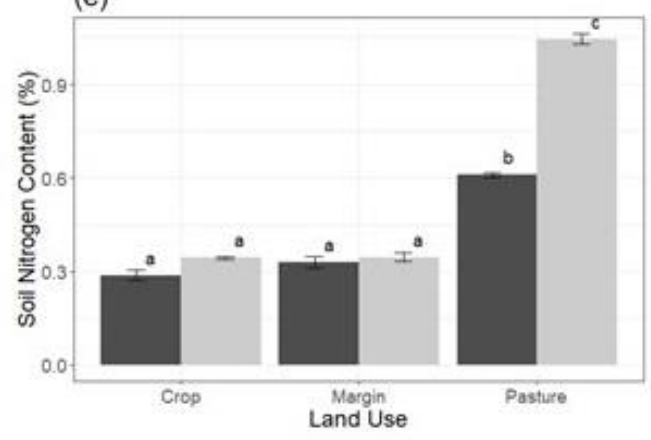

Flooding

Rarely Flooded

Frequently Flooded

256 Figure 2 - Mean (a) soil bulk density, (b) soil moisture content, (c) soil pH, (d) soil carbon content and (e) soil nitrogen content in soils under different land uses; crop, margin and pasture, and in areas of the field exposed to different flooding frequencies; rarely and frequently flooded $(n=$ 24 for rarely flooded crop, rarely flooded margin, frequently flooded crop, and frequently flooded margin; $n=36$ for rarely flooded pasture; $n=72$ for frequently flooded pasture). Error bars indicate standard errors of the mean. Bars in the same plot marked with the same letter as each other indicate treatments that are not significantly different from each other $(P<0.05)$. 


\subsection{Earthworm populations across different land uses and flooding frequencies}

264 There was a significant interaction between flooding and land use for all earthworm population factors

265 (Figure 3): abundance $(P<0.001)$, total biomass $(P=0.004)$, and the percentage of total earthworm 266 abundance represented by juveniles $(P=0.002)$.

267 Earthworm abundance was significantly lower in the frequently flooded crop and pasture soils relative 268 to the equivalent rarely flooded areas of the same soils. However, the abundance of earthworms in the 269 frequently flooded margin soils were higher than those in the equivalent rarely flooded soils. Total 270 earthworm biomass was significantly lower in the frequently flooded crop soils, but showed no response 271 to flooding frequency in either the margin or pasture soils. The percentage of the total earthworm 272 abundance represented by juvenile individuals was significantly lower in the frequently flooded area of 273 the pasture soils, compared to the rarely flooded area, but there was no significant difference between 274 the rarely and frequently flooded areas of crop or margin soils. 

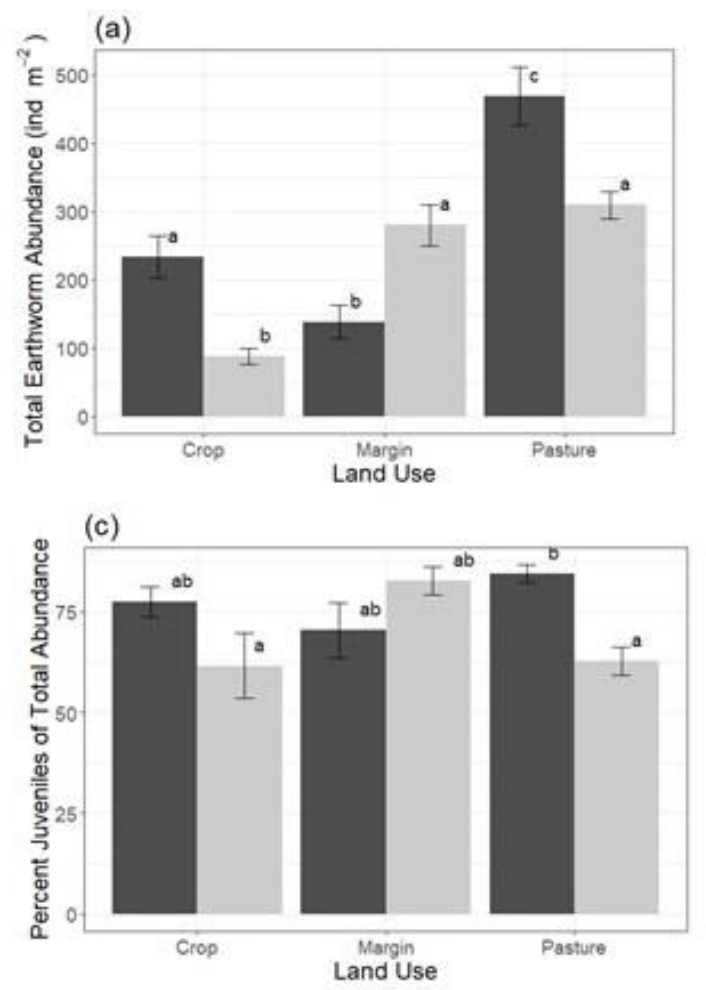

(b)

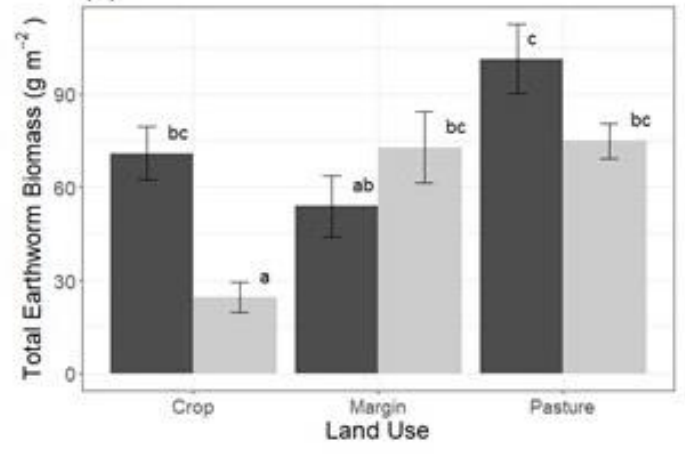

Flooding

Rarely Flooded

Frequently Flooded

278 Figure 3 - Mean (a) total earthworm abundance $\mathrm{m}^{-2}$, (b) total earthworm biomass $\left(\mathrm{g} \mathrm{m}^{-2}\right)$, and (c)

279 percentage of the total abundance of earthworms represented by juvenile individuals in soils

280 under different land uses; crop, margin and pasture, and areas of the field with different flooding

281 frequency; rarely and frequently flooded $(n=\mathbf{2 4}$ for rarely flooded crop, rarely flooded margin,

282 frequently flooded crop, and frequently flooded margin; $n=36$ for rarely flooded pasture; $n=72$

283 for frequently flooded pasture). Error bars indicate standard errors of the mean. Bars in the same

284 plot marked with the same letter as each other indicate treatments that are not significantly

285 different from each other $(P<0.05)$. 
The relative percentage difference in earthworm abundance and earthworm biomass between rarely and frequently flooded areas differed significantly between land uses $(P=0.01$ and $<0.05$ respectively $)$ (Figure 4). The relative percentage difference in abundance was negative in crop soils (-59.2\%) and pasture soils (-13.4\%) (i.e. earthworm abundance was lower in the frequently flooded areas than the rarely flooded areas), but was positive in margin soils (+140.6\%). Pairwise Wilcoxon post hoc testing showed that the differences between these land uses had significance levels of $P=0.057$ (crop and margin); $P=0.067$ (crop and pasture) and $P=0.057$ (margin and pasture). Similarly, the relative percentage difference in total earthworm biomass between rarely and frequently flooded areas was negative in the crop $(-63.5 \%)$ and pasture soils $(-9.7 \%)$, and positive in the margin soils. $(+78.7 \%)$. Pairwise Wilcoxon post hoc testing showed that the differences between these land uses had significance levels of $P=0.043$ (crop and margin); $P=0.043$ (crop and pasture) and $P=0.476$ (margin and pasture).
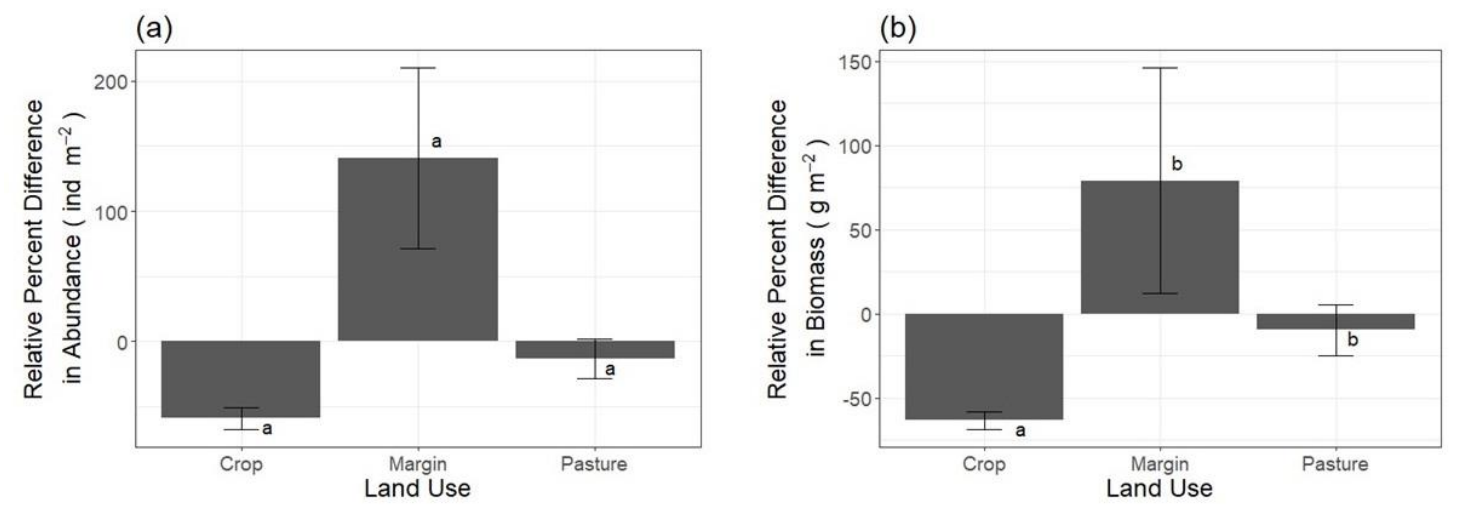

Figure 4 - Mean relative percentage difference in (a) earthworm abundance and (b) total earthworm biomass $\left(\mathrm{g} \mathrm{m}^{-2}\right)$, between rarely flooded and frequently flooded areas of crop, margin and pasture soils ( $n=4$ for crop; $n=4$ for margin; $n=6$ for pasture). Error bars indicate standard errors of the mean. Bars in the same plot marked with the same letter as each other indicate treatments that are not significantly different from each other $(P<0.05)$. 

chlorotica

309 Land use had no effect on the abundance of A. caliginosa, but significantly affected the abundance of 310 A. chlorotica $(P<0.001)$ (Figure 5). A. chlorotica was present exclusively as the green morph. Flooding 311 also affected the abundance of $A$. chlorotica $(P<0.001)$, but had no effect on the abundance of $A$. 312 caliginosa. Post hoc testing showed that the abundance of A. chlorotica was significantly higher in 313 frequently flooded pasture soils than in rarely flooded pasture soils, and all crop and margin soils. There 314 was no significant difference in the abundance of $A$. chlorotica between frequently flooded crop and 315 margin soils.

316 There was no significant effect of flooding on the biomass of individuals of either A. caliginosa or A. 317 chlorotica, and no effect of land use on the biomass of individuals of $A$. caliginosa. The combined 318 biomass of $A$. chlorotica individuals was significantly lower in the pasture soils than in the crop soils 319 ( $P<0.05$; Figure 5). The biomass of other species found in the soils at lower abundances can be found 320 in Table SI-2. 

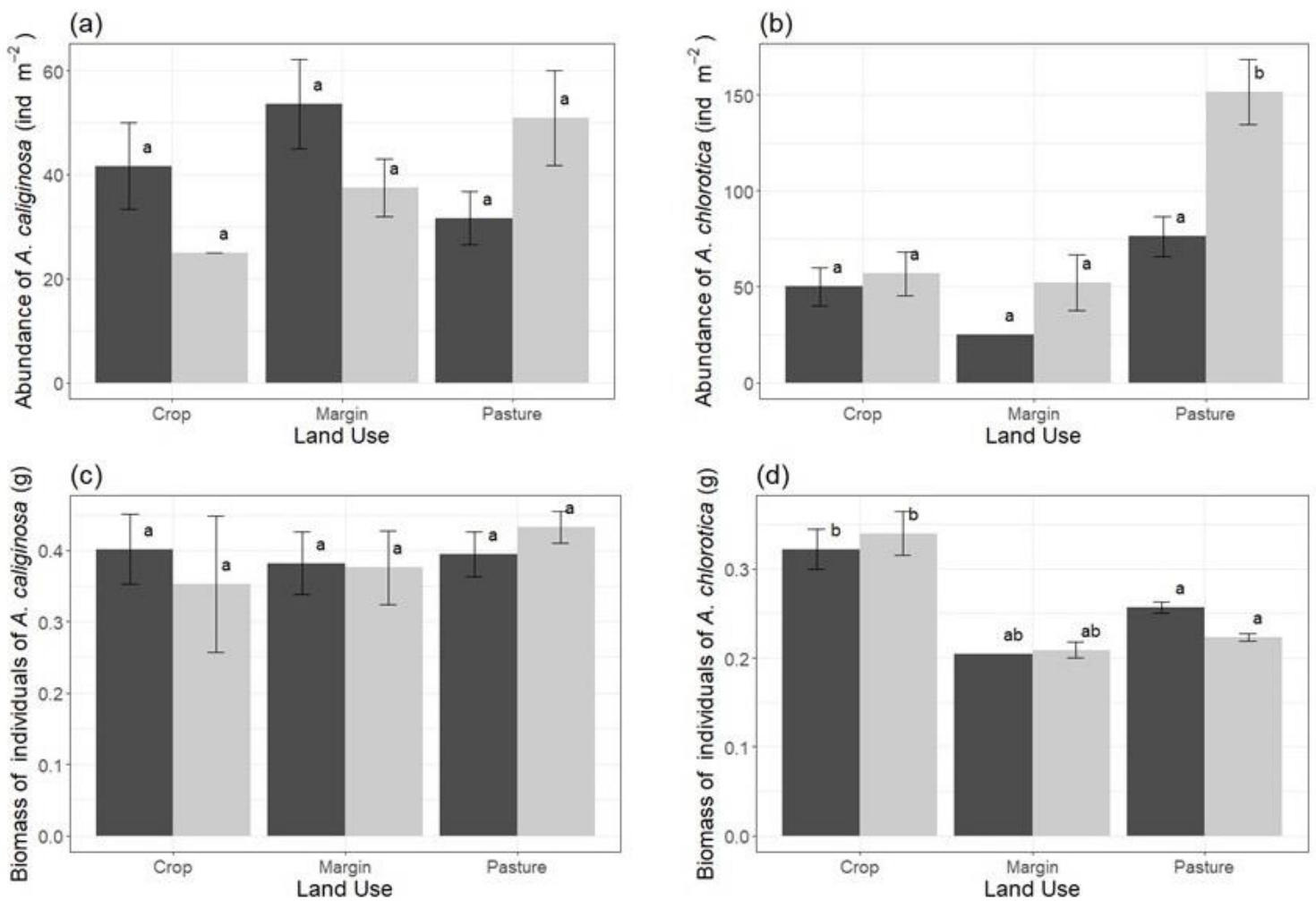

\section{Flooding}

Rarely Flooded Frequently Flooded

324 Figure 5 - Mean abundance of Aporrectodea caliginosa (a) ( $n=24$ for rarely flooded crop, rarely flooded margin, frequently flooded crop, and frequently flooded margin; $n=36$ for rarely flooded pasture; $\mathbf{n}=\mathbf{7 2}$ for frequently flooded pasture) and Allolobophora chlorotica (b) ( $\mathrm{n}=\mathbf{2 4}$ for rarely flooded crop, rarely flooded margin, frequently flooded crop, and frequently flooded margin; $\mathbf{n}$ = 36 for rarely flooded pasture; $\mathrm{n}=\mathbf{7 2}$ for frequently flooded pasture), and mean biomass $(\mathrm{g})$ of individuals of $\boldsymbol{A}$. caliginosa (c) ( $\mathrm{n}=10$ for rarely flooded crop; $\mathrm{n}=\mathbf{2}$ for frequently flooded crop; $n=15$ for rarely flooded margin; $n=9$ for frequently flooded margin; $n=34$ for rarely flooded pasture; $n=40$ for frequently flooded pasture) and $A$. chlorotica (d) $(n=28$ for rarely flooded crop; $n=25$ for frequently flooded crop; $n=23$ for rarely flooded margin; $n=1$ for frequently flooded margin; $n=177$ for rarely flooded pasture; $n=87$ for frequently flooded pasture) across the different land uses of crop, margin and pasture. Error bars indicate standard errors of the mean. Bars in the same plot marked with the same letter as each other indicate treatments that are not significantly different from each other $(P<0.05)$. 


\section{Discussion}

\subsection{Flooding causes changes in soil properties, reducing differences between crop and} margin soils.

As with other studies, there were differences in soil properties observed between crop and pasture soils (Figure 2), with higher bulk density, and lower carbon and nitrogen content, in the crop soils than in the pasture soils. Arable fields typically have a lower organic matter content than pasture fields (Bradley, 2005), due to a number of factors such as lower levels of plant root exudates and plant residue input, (Haynes and Beare, 1997; Guo and Gifford, 2002; Pausch and Kuzyakov, 2017), and cultivation; cultivation tends to break up aggregates that may protect soil carbon (Beare et al., 1994; Follett, 2001), and which are more protected in the higher root density systems observed in long term pasture compared to the low root density systems found under arable cultivation (Haynes et al., 1991). Arable fields also typically have higher bulk density than grazed pasture sites (Bharati et al., 2002) due to the use of heavy agricultural machinery leading to soil compaction, even in low trafficked fields (Hamza and Anderson, 2005). Despite these land use-induced differences between crop and pasture soils, the properties of soils from both land uses responded to flooding in a similar way. In common with other studies, we found that the soils from frequently flooded areas displayed a higher carbon content (Reddy and Patrick Jr, 1975; Zehetner et al., 2009; Cierjacks et al., 2010), lower soil bulk density (Bronik and Lal, 2005), and a higher soil moisture content than the soils from rarely flooded areas (Figure 2). The higher soil moisture content can be attributed to the flooding itself but also the increased water holding capacity associated with higher soil organic matter (Carter, 2002; Rawls et al., 2003). Differences in soil nitrogen content between the rarely and frequently flooded areas were only detected in the pasture soils, with significantly higher percent nitrogen observed in the frequently flooded areas. Levels of nitrate are typically high in the River Loddon and in the local groundwater (e.g. Bowes et al., 2018; Environment Agency, 2014; Howden et al., 2011) and it seems likely that this has led to the higher nitrate levels in the frequently flooded areas of the pasture field. Flooding reduced the differences observed between 
the crop and margin soils (Figure 2), with no significant difference between frequently flooded crop and margin soils observed for any of the soil properties.

Soil $\mathrm{pH}$ did not respond to flooding in the same way in the arable and pasture fields. All the soils were slightly acidic, but the rarely flooded margin soil was more acidic than the rarely flooded crop soil (Figure 2c). The rarely flooded margin soil contains more organic matter than the crop soil and the greater release of $\mathrm{H}^{+}$due to its aerobic decomposition explains the soil's lower $\mathrm{pH}$ (Porter et al., 1980). The frequently flooded margin soil had a significantly higher $\mathrm{pH}$ than the rarely flooded margin soil, as observed previously (Frohne et al., 2014), likely due to the consumption of $\mathrm{H}^{+}$ions during anaerobic decomposition of organic matter whilst the soils are flooded (Xu et al., 2006). Differences in organic matter content of the rarely and frequently flooded areas in the crop and pasture soils are insufficient to cause similar differences in soil $\mathrm{pH}$ between the rarely and frequently flooded areas.

All of the environmental factors measured in this study influence earthworm populations to a greater or lesser degree. The reduced plant residue input observed in crop soil compared to field margin or pasture soil (Guo and Gifford, 2002) has been shown to reduce earthworm populations, with populations increasing in mulched crop soils compared to un-mulched soils (Pelosi et al., 2009), while the greater below ground root density in pasture soils than in arable soils leads to greater quantities of dead root matter for earthworm consumption (Curry and Schmidt, 2007; Bernier, 1998). The different aboveground plant covers present in pasture and arable soils can also lead to differences in the composition of the rhizosphere, with soil bacterial populations driven in part by different plant root exudates (Dennis et al., 2010; Dey et al., 2012), again influencing soil carbon dynamics (Haichar et al, 2008) and acting as a food source for earthworms (Edwards and Fletcher, 1988). Soil bulk density can influence earthworm burrowing activity, but the responses to compacted soil vary between earthworm ecotypes (Kretzschmar, 1991; Joschko et al., 1989; Langmaack et al., 1999). Soil moisture can influence a range of earthworm behaviours, from escaping behaviour in flooded conditions (Darwin, 1881; Roots, 1956; Zorn et al., 2005) to aestivation in hot and dry conditions (Gerard, 1967). It is evident from the literature that flooding and land use lead to changes in soil properties, and that these, together with a range of other variables such as predator numbers and local weather conditions, in turn influence earthworm 
populations. By sampling soils from the same field but under different flooding regimes, we have attempted to control for these confounding variables as much as possible in order to understand how the interaction of flooding and land use impacts earthworm populations.

392

393

\subsection{The dual stresses of flooding and land use reduces earthworm populations more}

\section{than the individual stressors}

As expected, the earthworm populations were lower in the crop than in the pasture soils (Curry et al., 2002; Boag et al., 1997; Roarty and Schmidt, 2013). Our observed average abundances of $233.33 \pm$ 153.84 individuals $\mathrm{m}^{-2}$ in the rarely flooded crop soils lie in the $150-320$ individuals $\mathrm{m}^{-2}$ range of abundances in crop soils reported in the literature for temperate climate conventional arable management (Poier and Richter, 1992; Binet and Le Bayon, 1998; Curry et al., 2002; Roarty and Schmidt, 2013; Pelosi et al., 2014), while our observed abundances in the frequently flooded crop soils $\left(87.50 \pm 58.98\right.$ individuals $\left.\mathrm{m}^{-2}\right)$ fall below this range. However, our observed abundances in both the rarely and frequently flooded field margins were lower than those reported by Roarty and Schmidt (470 \pm 47 individuals $\mathrm{m}^{-2}$ compared to $138.54 \pm 120.68$ and $280.21 \pm 149.63$ individuals $\mathrm{m}^{-2}$ in the rarely and frequently flooded field margins respectively). We did observe high levels of deviation within the crop and field margin soils, which may be attributed to variability across seasons or reflect patchy distribution of resources in arable soils (Ettema and Wardle, 2002). Within pasture soils, our observations of $468.75 \pm 253.92$ and $309.38 \pm 169.68$ individuals $\mathrm{m}^{-2}$ in the rarely and frequently flooded soils respectively fall within the literature reported ranges of $218-550$ individuals $\mathrm{m}^{-2}$ (Nuuntinen et al., 1998; Didden, 2001; Piotrowska et al., 2013).

In this study, the relative difference in the total earthworm abundance and biomass between the rarely and frequently flooded areas was greater in the crop $(-59.18 \%$ and $-63.49 \%$ respectively) than in the pasture (-13.39\% and $-9.66 \%$ respectively) soils (Figure 4). Whilst we do not have quantitative data on the frequency and duration of flooding at the two sites, which could at least in part explain these differences, the populations in the frequently flooded crop soils will have been impacted by two stressors, conventional arable cultivation (leading to compaction, reduced organic matter content, soil 
415 disturbance) and flooding, whereas populations in the frequently flooded pasture soils are only impacted 416 by flooding. Barnes and Ellis (1979) also found greater reductions in earthworm populations in sites 417 subject to two rather than one stressor, though in their case they compared sites stressed by both 418 ploughing and straw stubble burning with sites that still experienced straw stubble burning but were 419 direct drilled rather than ploughed. In contrast to the crop and pasture soils, earthworm abundance and 420 biomass in the margin soils showed a relative increase in the frequently flooded area, compared to the rarely flooded area $(+140.56 \%$ and $+78.74 \%$ respectively) (Figure 4$)$. This was unexpected, but may be due to the greater organic matter content of the soil caused by flooding and the associated increase in soil moisture leading to soil conditions more suitable for larger earthworm populations than in the rarely flooded margin soils. This hypothesis is supported by the fact that the populations found in the frequently flooded margin soils are not significantly different to those found in the frequently flooded pasture soils.

The total earthworm biomass was only significantly different between the rarely and frequently flooded areas in the crop soils. Since total biomass was not lower in the frequently flooded areas in the pasture soils but total abundance was for both crop and margin soils this suggests that flooding led to an increase in the biomass of earthworm individuals in the pasture soil relative to the crop soil. There is evidence that earthworm populations are highly density dependent (Uvarov, 2009), with negative effects of large, multispecies populations on the growth rates of individuals (Eriksen-Hamel and Walen, 2007). In the pasture soils the relative increase in the biomass of earthworm individuals in the frequently flooded area could be due to a reduction in competition between individuals, but may also be due to the reduced juvenile proportion of the population (Figure 3c), with a higher proportion of larger bodied adult individuals present in the population. The lack of a similar response in individual biomass due to reduced numbers in the frequently flooded arable soils may reflect food limitations or reduced competition already being present in the rarely flooded arable areas due to the lower abundances relative to the pasture soil. In the margin soils, the higher earthworm abundance in the frequently flooded area is not accompanied by a higher total earthworm biomass, suggesting a reduction in the biomass of 
441 individuals due to competition, particularly between species which overlap niches (Lowe and Butt, 442 1999).

443 The earthworm species present at the highest abundance in both fields were A. chlorotica and $A$. 444 caliginosa. This is not unexpected; a Natural England survey in 2014 found them to be the most common earthworm species in the UK, together comprising 53\% of UK earthworm populations (Natural England, 2014). A. caliginosa showed no response to flooding or land use but A. chlorotica was most abundant in the frequently flooded pasture soils (Figure 5). As small bodied individuals that belong to the endogeic ecotype, which forage in the upper $20 \mathrm{~cm}$ of soil rather than on the soil surface (Bouché, 1977), earthworms such as A. chlorotica and A. caliginosa are typically less susceptible to the crush damage caused by tillage that leads to the death of larger bodied earthworms (Wyss and Glasstetter, 1992). The lower abundance of A. chlorotica in the crop and margin soils than in the pasture soils can therefore be attributed to poor availability of soil organic matter in crop soils (Reeleeder et al., 2006), which is one of the drivers of low earthworm abundance typically observed in arable soils (Curry et al., 2002; Boag et al., 1997; Roarty and Schmidt, 2013). The relatively high abundance of $A$. chlorotica in the frequently flooded pasture soils compared to the rarely flooded pasture soils most likely reflects the documented preference of the green morph of A. chlorotica for moist soils (Satchell, 1967). A. chlorotica individuals had a greater biomass in the crop than in the pasture soil (Figure 5). Reduced competition from a less abundant and less diverse population in the crop soil may have allowed individuals of $A$ chlorotica to reach a greater individual biomass. The lack of similar responses for $A$. caliginosa, may be due to niche overlap competition with $A$. chlorotica occurring at equal pressure across all soil uses, but this is not certain and would need further investigation. The relative differences in biomass of individuals between the rarely and frequently flooded sites predicted for the different land uses on the basis of the total abundance and biomass data were not observed for either A. caliginosa or A. chlorotica suggesting that either the differences may have been due to the low abundance species for which statistical testing is not reliable (for example L. terrestris, a high biomass earthworm, was not recorded in the frequently flooded arable soil, Table SI-1) or that, for the pasture soil at least, the differences are due to differences in the relative proportion of juveniles. 
There was a significantly lower proportion of juveniles in the population of the frequently flooded pasture soils than in the rarely flooded pasture soil. No significant difference was observed with flooding in the crop or the margin soils or between land uses. These findings are in contrast to observations made in the literature. Pižl (1992) found that populations in regularly ploughed crop soils had a higher proportion of juvenile earthworms than undisturbed regions, while Plum and Filser (2005) suggested that, following flooding, the proportion of the population represented by juveniles can increase due to the hatching of cocoons and the death of adults caused by the flooding event. In this study, the relatively low percentage of juveniles within the frequently flooded pasture soils may be due to the soil moisture contents. A study by Evans and Guild (1948) found a horseshoe relationship between soil moisture and cocoon production of A. chlorotica, with production peaking at between $28 \%$ and $42 \%$ soil moisture. Average soil moisture content of the frequently flooded pasture soils was $94 \%$ $( \pm 25 \%$; Figure $2 \mathrm{~b}$ ); it may be the case that the higher soil moisture content of this soil resulted in lower cocoon production overall, leading to a reduced juvenile proportion of the population. The observed results may also be attributed to the effect of reduced competition in the crop soils, with larger bodied individuals in the crop soils better able to maintain cocoon production during the unfavourable conditions caused by flooding, while the higher availability of food sources for earthworms in the margins may lead to higher cocoon production by populations inhabiting margin soils (Evans and Guild, 1948).

\subsection{Limitations and further study}

There are limitations to this study that must be considered. In this study, we did not determine whether groundwater or riverine flooding occurred. This merits further study, as high groundwater levels may not always be evident on the soil surface, and yet still inundate soil where earthworms are active. over longer periods of time are necessary to provide greater levels of detail about the earthworm populations and biodiversity. Such studies would increase understanding of earthworm population 
resilience, and information on how the impact of flooding on earthworm populations could ultimately

494 affect the ecosystem services provided by arable and pasture soils.

\section{5. Conclusion}

496

497

498

499

500

501

Many of the soil properties measured differed, as expected, between the crop, margin, and pasture soils. The bulk density in the crop and margin soils was higher than the pasture soils, while soil moisture, percent carbon, and percent nitrogen were lower. Similarly, as expected, soil bulk density was lower and soil moisture content, $\mathrm{C}$ content and $\mathrm{N}$ content higher in frequently flooded areas of the fields due to accumulation and reduced degradation of organic matter, compared to the rarely flooded areas. All the soils were slightly acidic but only the margin soil showed a significantly higher $\mathrm{pH}$ in the frequently flooded area, likely linked to the consumption of $\mathrm{H}^{+}$ions during anaerobic respiration. With flooding the significant differences in bulk density, soil moisture, $\mathrm{pH}$, percent carbon, and percent nitrogen between the field margin and the crop soils disappeared. This indicates that increased frequency of flooding overrides some of the effects of land use on soil properties, likely by increasing the organic matter content of the frequently flooded soils.

Earthworm populations differed with land use. Total earthworm abundance and biomass was greater in the pasture than in the arable soils. Flooding led to lower earthworm abundance in both pasture and crop soil, and reductions in total earthworm biomass in crop soils. However, the relative difference in population and total biomass with flooding was greater in the crop soils than in the pasture soils. In contrast to the arable and pasture soils, total earthworm abundance was increased in the margin soils with frequent flooding, which may be attributed to the flooding-induced soil environmental properties making the soils more suitable for larger earthworm populations. The percentage of total earthworm abundance represented by juveniles was significantly lower in frequently flooded pasture soils than in rarely flooded pasture soils, but there was no significant response to flooding in crop or margin land uses. 
517 The results suggest that earthworm populations are reduced the most when subject to the dual stresses

518 of arable land use and flooding. With changing weather patterns increasing the likelihood of flooding

519 events, including in areas not previously known to flood, earthworm populations in arable soils may be

520 further reduced, leading to a reduction in the ecosystem services they provide and an increase in the

521 time it takes soils to recover following a flooding event.

\section{Acknowledgements}

523 The authors would like to acknowledge the financial support from White Rose University Consortium

524 through the BIOchemical-physical-biological function of Sludge in Agriculture Soils (BioSAS, 2016-

525 2020) PhD studentship network. We acknowledge the help of Jonathan Skidmore, English Nature in 526 identifying the arable field site and Mark Marley for permission to sample there. We thank James

527 Lamburn for granting permission to sample on the pasture field site and his observations on the flooding 528 regime there. Jamal Hallam, Miranda Prendergast-Miller, Henny Omosigho, and Alvaro Leon are 529 thanked for assistance with field work. We thank three anonymous reviewers for their comments which 530 helped improve this paper. The graphical abstract was created using Biorender.com.

\section{$531 \quad$ 6. References}

532 ADAS, 2014. Impact of 2014 Winter Floods on Agriculture in England [Leaflet]

533 Ausden, M., Sutherland, W.J., James, R. 2001. The Effects of Flooding Lowland Wet Grassland on Soil 534 Macroinvertebrate Prey of Breeding Wading Birds. Journal of Applied Ecology 38: 320-338.

535 Ball, D., Tapp, L., Gordon, F.C., Potter, D.A. 1986. Effects of Pesticides on Earthworm Populations in 536 Kentucky Bluegrass, 1985. Insecticide and Acaricide Tests 11(1): 395 - 396.

537 Barley, K.P., Jennings, A.C. 1959. Earthworms and Soil Fertility. III. The Influence of Earthworms on 538 the Availability of Nitrogen. Australian Journal of Agricultural Research 10(3); 364 - 370. 
539 Barnes, B.T., Ellis, F.B. 1979. Effects of Difference Methods of Cultivation and Direct Drilling, and

540 Disposal of Straw Residues, on Populations of Earthworms. Journal of Soil Science 30(4): 669 - 679.

541 Beare, M.H., Hendrix, P.F., Coleman, D.C. 1994. Water-Stable Aggregates and Organic Matter 542 Fractions in Conventional- and No-Tillage Soils. Soil Science Society of America Journal 58(3): 777 543786.

544 Bernier, N. 1998. Earthworm Feeding Activity and Development of the Humus Profile. Biology and 545 Gertility of Soils 26(3): $215-223$

546 Bertrand, M., Barot, S., Blouin, M., Whalen, J., de Oliveira, T., Roger-Estrade, J. 2015. Earthworm 547 Services for Cropping Systems. A Review. Agronomy for Sustainable Development 35(2): 553 - 567.

548 Bharati, L., Lee, K.-H., Isenhart, T.M., Schultz, R.C. 2012. Soil-Water Infiltration under Crops, Pasture, 549 and Established Riparian Buffer in Midwestern USA. Agroforestry Ecosystems 56(3): 249 - 257.

550 Binet, F. and Le Bayon, R.C. 1998. Space-time Dynamics in situ of Earthworm Casts under Temperate 551 Cultivated Soils. Soil Biology and Biochemistry 31(1): 85 - 93.

552 Blöschl, G., Hall, J., Parajka, J., Perdigão, R.A., Merz, B., Arheimer, B., Aronica, G.T., Bilibashi, A., 553 Bonacci, O., Borga, M. and Čanjevac, I., 2017. Changing climate shifts timing of European floods. $554 \quad$ ScienceW 357(6351): $588-590$.

Blouin, M., Hodson, M.E., Delgado, E.A., Baker, G., Brussard, L., Butt, K.R., Dai, J., Dendooven, L., Peres, G., Tondoh, J.E., Cluzeau, D., Brun, J.-J. 2013 A Review of Earthworm Impact on Soil Function and Ecosystem Services. European Journal of Soil Science 64: 161-182. 
561 Boström, U. 1995. Earthworm Populations (Lumbricidae) in Ploughed and Undisturbed Leys. Soil and 562 Tillage Research 35(3): 125 - 133.

563 Bouché, M. B., 1977. Strategies Lombriciennes. Ecological Bulletins 25: 122-132.

564 Bowes, M.J., Armstrong, L.K., Harman, S.A., Wickham, H.D., Nicholls, D.J.E., Scarlett, P.M., Roberts, 565 C., Jarvie, H.P., Old, G.H., Gozzard, E., Bachiller-Jareno, N., Read, D.S., 2018. Weekly water quality 566 monitoring data for the River Thames (UK) and its major tributaries (2009-2013): the Thames Initiative 567 research platform. Earth System Science Data 10: 1637-1653.

568 Bradley, R.I., Milne, R., Bell, J., Lilly, A., Jordan, C., Higgins, A. 2005. A Soil Carbon and Land Use 569 Database for the United Kingdom. Soil Use and Management 21(4): 363 - 369.

570 Bronick, C.J., Lal, R. 2005. Soil Structure and Management: A Review. Geoderma 124(1-2): 3 - 22.

Bronstert, A., 2003. Floods and climate change: interactions and impacts. Risk Analysis: An 572 International Journal 23(3): 545 - 557.

Carter, M.R. 2002. Soil Quality for Sustainable Land Management. Agronomy Journal 94(1): 38 - 47

Cierjacks, A., Kleinschmit, B., Babinsky, M., Kleinschroth, F., Markert, A., Menzel, M., Ziechmann, U., Schiller, T., Graf, M., Lang, F. 2010. Carbon Stocks of Soil and Vegetation on Danubian Floodplains. Journal of Plant Nutrition and Soil Science 173(5): 644 - 653.

Curry, J.P., Byrne, D., Schmidt, O. 2002. Intensive Cultivation can Drastically Reduce Earthworm 578 Populations in Arable Land. European Journal of Soil Biology 38(2): 127 - 130.

Curry, J.P., Schmidt, O. 2007. The Feeding Ecology of Earthworms - A Review. Pedobiologia 50(6): $463-477$ Observations on their Habits Illustrated Edition. Milton Keynes: Dodo Press. 
583

584

585

586

587

588

589

590

591

592

593

594

595

596

597

598

599

600

601

602

603

604

605

Dennis, P.G., Miller, A.J., Hirsch, P.R. 2010. Are Root Exudates More Important than Other Sources of Rhizodeposits in Structuring Rhizosphere Bacterial Communities? FEMS Micrbial Ecology 72(3): $313-327$

Dey, R., Pal, K.K., Tilak, K.V.B.R. 2012. Influence of Soil and Plant Types on Diversity of Rhizobacteria Proceedings of the National Academy of Sciences, India Section B: Biological Sciences 82(3): $341-352$

Didden, W.A.M. 2001. Earthworm Communities in Grasslands and Horticultural Soils. Biology and Fertility of Soils 33(2): $111-117$.

Edwards, C.A., Fletcher, K.E. 1988. Interactions Between Earthworms and Microorganisms in OrganicMatter Breakdown. Agriculture, Ecosystems \& Environment 24(1-3): 235 - 247.

Environment Agency, 2014. The Loddon management catchment: A summary of information about the water environment in the Loddon management catchment. Environment Agency, Bristol, UK.

Ernst, G., Felten, D., Vohland M., Emmerling, C. 2009. Impact of Ecologically Different Earthworm Species on Soil Water Characteristics. European Journal of Soil Biology 45(3): 207 - 213.

Eriksen-Hamel, N.S., Whalen, J.K. 2007. Competitive Interactions Affect the Growth of Aporrectodea caliginosa and Lumbricus terrestris (Oligochaeta: Lumbricidae) in Single- and Mixed-Species Laboratory Cultures. European Journal of Soil Biology 43(3): 142 - 150.

Ettema, C.H., Wardle, D.A. 2002. Spatial Soil Ecology. Trends in Ecology \& Evolution 17(4): 177 183.

Evans, A.C., Guild, W.M. 1948. Studies on the Relationships between Earthworms and Soil Fertility: IV. On the Life Cycles of Some British Lumbricidae. Annals of Applied Biology 35(4): 471 - 484.

Follett, R.F. 2001. Soil Management Concepts and Carbon Sequestration in Cropland Soils. Soil and Tillage Research 61(1-2): $77-92$. 
606 Frohne, T., Diaz-Bone, R.A., Laing, G.D., Rinklebe, J. 2014. Impact of Systematic Change of REDOX

607 Potential on the Leaching of $\mathrm{Ba}, \mathrm{Cr}, \mathrm{Sr}$, and V from a Riverine Soil into Water. Journal of Soils and 608 Sediments 15: $623-633$.

609 Funmilayo, O. 1979. Food Consumption, Preferences and Storage in the Mole. Acta theriologica 24: $610 \quad 379-389$.

611 Gerard, B.M. 1967. Factors Affecting Earthworms in Pastures. Journal of Animal Ecology 36(1): 235 $612-252$

613 Guo, L.B., Gifford, R.M. 2002. Soil Carbon Stocks and Land Use Change: A Meta-Analysis. Global 614 Change Biology 8(4): $345-360$.

615 Haichar, F., Marol, C., Berge, O., Rangel-Castro, J., Porsser, J., Balesdent, J., Heulin, T., Achouak, W. 616 2008. Plant Host Habitat and Root Exudates Shape Soil Bacterial Community Structure. ISME Journal $617 \quad 2(12): 1221-1230$.

618 Hamza, M. A., Anderson, W. K. 2005. Soil compaction in cropping systems - A review of the nature, 619 causes and possible solutions. Soil \& Tillage Research, 82: 121-145.

620 Hallam, J., Hodson, M.E. 2020. Impact of Different Earthworm Ecotypes on Water Stable Aggregates 621 and Soil Water Holding Capacity. Biology and Fertility of Soils. Doi.org/10.1007/s00374-020-014326225.

623 Hallam, J., Berdeni, D., Grayson R., Guest, E.J., Holden, J., Lappage, M.G., Prendergast-Miller, M.T., 624 Robinson, D.A., Turner, A., Leake, J.R., Hodson M.E. 2020. Effect of Earthworms on Soil Physico625 Hydraulic and Chemical Properties, Herbage Production, and Wheat Growth on Arable Land Converted 626 to Ley. Science of the Total Environment 713136491.

627 Harvey, R.J., Chadwick, D.R., Sánchez-Rodríguez, A.R. and Jones, D.L., 2019. 628 Agroecosystem Resilience in Response to Extreme Winter Flooding. Agriculture, Ecosystems $629 \&$ Environment 279: 1 - 13. 
630 Haynes, R.J., Beare, M.H. 1997. Influence of Six Crop Species on Aggregate Stability and 631 Some Labile Organic Matter Fractions. Soil Biology and Biochemistry 29(11 - 12): 1647 6321653.

633 Haynes, R.J., Swift, R.S., Stephen, R.C. 1991. Influence of Mixed Cropping Rotations (Pasture 634 - Arable) on Organic Matter Content, Water Stable Aggregation and Clod Porosity in a Group of Soils. Soil and Tillage Research 19: $77-87$.

636 Hirabayashi, Y., Mahendran, R., Koirala, S., Konoshima, L., Yamazaki, D., Watanabe, S., Kim, H., 637 Kanae, S. 2013. Global Flood Risk Under Climate Change. Nature Climate Change 3(9): 816 - 821.

638 Hirabayashi, Y., Kanae, S. 2009. First Estimate of the Future Global Population at Risk of Flooding. 639 Hydrological Research Letters 3: 6 - 9.

640 Holden, J., Grayson, R., Berdeni, D., Bird, S., Chapman, P.J., Edmondson, J.L., Firbank, L.G., 641 Helgason, T., Hodson, M.E., Hunt, S., Jones, D.T., Lappage, M., Marshall-Harries E., Nelson, M., 642 Prendergast-Miller, M.F., Shaw, H., Wade, R., Leake, J.R. 2019 The Role of Hedgerows in Soil 643 Functioning Within Agricultural Landscapes. Agriculture, Ecosystems and Environment 273: 1 - 12.

644 Howden, N.J.K., Burt, T.P., Worrall, F., Mathias, S., Whelan, M.J., 2011. Nitrate pollution in 645 intensively farmed regions: What are the prospeces for sustaining high-quality groundwater? Water 646 Resources Research 47 W00L02.

647 Johnston, C.A., Bubenzer, G.D., Lee, G.B., Madison, F.W., McHenry, J.R. 1984. Nutrient Trapping by 648 Sediment Deposition and Seasonally Flooded Lakeside Wetland 1. Journal of Environmental Quality 649 13(2): $283-290$.

650 Jones, C.G., Lawton, J.H., Shachak, M. 1994. Organisms as Ecosystem Engineers. Oikos 69(3): 373651 386. 
652 Jones, D.T., Lowe, C.N. 2016. Key to Common British Earthworms. The OPAL Soil and Earthworm 653 Survey. Imperial College London.

654 Joschko, M., Diestel, H., Larink, O. 1989. Assessment of Earthworm Burrowing Efficiency in 655 Compacted Soil with a Combination of Morphological and Soil Physical Measurements. Biology and 656 Fertility of Soils, 8: 191-196.

657 Kiss, T.B.W. 2019. Earthworms, Flooding, and Sewage Sludge. PhD Thesis, University of York.

658 Kretzschmar, A. 1991. Burrowing Ability of the Earthworm Aporrectodea longa Limited by Soil 659 Compaction and Water Potential. Biology and Fertility of Soils, 11: 48-51.

660 Kundzewicz, Z.W., Kanae, S., Seneviratne, S.I., Handmer, J., Nicholls, N., Peduzzi, P., Mechler, R., 661 Bouwer, L.M., Arnell, N., Mach, K, Muir-Wood, R. 2014. Flood Risk and Climate Change: Global and 662 Regional Perspectives. Hydrological Sciences Journal 59(1): 1 - 28.

663 Lane, S.N., 2017. Natural flood management. Wiley Interdisciplinary Reviews: Water 4(3): p.e1211.

664 Langmaack, M., Schrader, S., Rapp-Bernhardt, U., Kotzke, K. 1999. Quantitative Analysis of 665 Earthworm Burrow Systems with Respect to Biological Soil-Structure Regeneration after Soil 666 Compaction. Biology and Fertility of Soils, 28: 219-229.

667 Lawton, J.H., 1994. What Do Species Do in Ecosystems? Oikos 71(3): 367-374.

668 Lowe, C.N., Butt, K.R. 1999. Interspecific Interactions Between Earthworms: A Laboratory-Based 669 Investigation. Pedobiologia 43(6): 808 - 817.

670 Lowe, C.N., Butt, K.R. 2002. Growth of Hatching Earthworm in the Presence of Adults: Interactions 671 in Laboratory Culture. Biology and Fertility of Soils 35(3): 204 - 209.

672 Macdonald, D.W., 1980. The Red Fox, Vulpes vulpes, as a Predator upon Earthworms, Lumbricus 673 terrestris. Zeitshrift für Tierpsychologie 52(2): 171-200.

674 Maeder, P., Fliessbach, A., Dubois, D., Gunst, L., Fried, P., Niggli, U. 2002. Soil Fertility and 675 Biodiversity in Organic Farming. Science 296(5573): 1694 - 1697. 
676 Meysman, F.J., Middelburg, J.J. and Heip, C.H., 2006. Bioturbation: a fresh look at Darwin's last idea.

677 Trends in Ecology \& Evolution 21(12): 688 - 695.

678

Natural England, 2014. Earthworms in England: Distribution, Abundance and Habitats (NECR145)

679

Nuutinen, V., Pitkänen, J., Kuusela, E., Widbom, T., Lohilahti, H. 1998. Spatial Variation of an

680 Earthworm Community Related to Soil Properties and Yield in a Grass-Clover Field. Applied Soil $681 \quad$ Ecology 8(1-3): $85-94$.

682

Pausch, J., Kuzyakov, Y. 2017. Carbon Inputs by Roots into the Soil: Quantification of Rhizodeposition 683 from Root to Ecosystem Scale. Global Change Biology 24(1): 1 - 12.

684

Pelosi, C., Barot, S., Capowiez, Y., Hedde, M., Vandenbulcke, F. 2013. Pesticides and Earthworms. A 685 Review.. Agronomy for Sustainable Development 34(1): 199 - 229.

686

Pelosi, C., Bertrand, M., Capowiez, Y., Boizard, H., Roger-Estrade, J. 2009. Earthworm Collection 687 from Agricultural Fields: Comparisons of Selected Expellants in Presence/Absence of Hand-Sorting. 688 European Journal of Soil Biology 45(2): 176 - 183.

689

Pelosi, C., Pey, B., Hedde M., Caro, G., Capowiez, Y, Guernion, M., Peigné, J., Piron, D., Bertrand, 690 M., Cluzeau, D. 2014. Reducing Tillage in Cultivated Fields Increases Earthworm Functional Diversity. 691 Applied Soil Ecology 83: 79 - 87.

692

Piotrowska, K., Connolly, J., Finn, J., Black, A., Bolger, T., 2013. Evenness and Plant Species Identity 693 Affect Earthworm Diversity and Community Structure in Grassland Soils. Soil Biology and 694 Biochemistry, 57: 713-719.

695 Pižl, V. 1992. Succession of Earthworm Populations in Abandoned Fields. Soil Biology and 696 Biochemistry 24(12): $1623-1628$. 
Plum, N.M., Filser, J. 2005. Floods and Drought: Response of Earthworms and Potworms (Oligochaeta: Lumbricidae, Enchytraeidae) to Hydrological Extremes in Wet Grassland. Pedobiologia 49(5): 443 453.

Poier, K.R., Richter, J. 1992. Spatial Distribution of Earthworms and Soil Properties in an Arable Loess Soil. Soil Biology and Biochemistry 24(12): 1601 - 1608.

Ponnamperuma, F. N. 1984. Effects of Flooding on Soils. In: Kozlowski, T.T, ed. Flooding and Plant Growth. Orlando: Academic Press, 9 - 45.

Porter, W.M., Cox, W.J., Wilson, I. 1980. Soil Acidity: Is it a problem in Western Australia? Journal of the Department of Agriculture, Western Australia, Series 4 21(4): 126 - 133.

Prudhomme, C., Jakob, D., Svensson, C. 2003. Uncertainty and Climate Change Impact on the Flood Regime of Small UK Catchments. Journal of Hydrology 277: 1-23. Organic Carbon on Soil Water Retention. Geoderma 116(1-2): 61 - 76.

R Core Team 2019. R: A Language and Environment for Statistical Computing. R Foundation for Biochemistry 7(2); $87-94$. 
719 Communities but do not Increase In-Field Populations. Agriculture, Ecosystems \& Environment 170: $720 \quad 45-55$.

721 Roots, B. I. 1956. The Water Relations of Earthworms .2. Resistance to Desiccation and Immersion, 722 and Behaviour When Submerged and When Allowed a Choice of Environment. Journal of 723 Experimental Biology, 33, 29-44.

724 Satchell, J.E., 1967. Colour Dimorphism in Allolobophora chlorotica Sav. (Lumbricidae). Journal of 725 Animal Ecology 36(3): 623-630.

726 Scheu, S., 1987. The role of substrate feeding earthworms (Lumbricidae) for bioturbation in a 727 beechwood soil. Oecologia, 72(2): $192-196$.

Scheu, S., Theenhaus, A, Jones, H. 1999. Links between the Detritivore and the Herbivore System: Effects of Earthworms and Collembola on Plant Growth and Aphid Development. Oecologia 119(4): $541-551$. in Woodland Flooding Systems Used for Drinking Water Production. Applied Soil Ecology 39(3): 342 $-351$.

Sizmur, T., Hodson, M.E. 2009. Do Earthworms Impact Metal Mobility and Availability in Soil?-A review. Environmental Pollution 157(7):1981 - 1989. Toxic Elements: Results of a Meta-Analysis. Soil Biology and Biochemistry 107865. of Zoology: London 215: 360-362.

740 Stork, N.E., Eggleton, P. 1992. Invertebrates as Determinants and Indicators of Soil Quality. American Journal of Alternative Agriculture 7: 38 - 47. 
Thien, S.J., 1979. A flow diagram for teaching texture-by-feel analysis. Journal of Agronomic Education 8(1): 54 - 55 .

Tomati, U., Galli, E. 1995. Earthworms, Soil Fertility, and Plant Productivity. Acta Zoologica Fennica. 196: $11-14$.

Tomati, U., Grappelli, A., Galli, E. 1988. The Hormone-Like Effect of Earthworm Casts on Plant Growth. Biology and Fertility of Soils 5(4): 288 - 294.

Tomlin, A.D., Miller, J.J. 1988. Impact of Ring-Billed Gull (Larus delawarensis Ord.) Foraging on Earthworm Populations of Southwestern Ontario Agricultural Soils. Agriculture, Ecosystems \& Environment 20(3): 165 - 173.

Uvarov, A.V. 2009. Inter- and Intraspecific Interactions in Lumbricid Eathworms: Their Role for Earthworm Performance and Ecosystem Functioning. Pedobiologia 53(1): 1 - 27. van Groenigen, J.W., Lubbers, I.M, Vos, H.M.J., Brown, G.G., De Deyn, G. B., van Groenigen, K.J. 2014. Earthworms Increase Plant Production: A Meta-Analysis. Scientific Reports 4: 6365. Higler, L.W.G., Verhoeven, J.T.A. 2009. Importance of Sediment Deposition and Denitrification for Nutrient Retention in Floodplain Wetlands. Applied Vegetation Science 9(2): 163 - 174.

Whalen, J.K. and Parmelee, R.W., 1999. Quantification of nitrogen assimilation efficiencies and their use to estimate organic matter consumption by the earthworms Aporrectodea tuberculata (Eisen) and Lumbricus terrestris L. Applied Soil Ecology 13: 199 - 208. and Diversity of Invertebrate and Plant Foods of Granivorous Birds in Northern Europe in Relation to Agricultural Change. Agriculture, Ecosystems \& Environment 75: 13 - 30. 
765 Wyss, E., Glasstetter, M. 1992. Tillage Treatments and Earthworm Distribution in a Swiss Experimental

766 Corn Field. Soil Biology and Biochemistry. 24(12): 1635 - 1639.

767 Xu, J.M., Tang, C., Chen, Z.L. 2006. The Role of Plant Residues in pH Change of Acid Soils Differing 768 in Initial pH. Soil Biology and Biochemistry 38(4): 709 - 719.

769 Zaborski, E.R. 2003. Allyl Isothiocyanate: An Alternative Chemical Expellant for Sampling 770 Earthworms. Applied Soil Ecology 22(1): 87 - 95.

771 Zehetner, F., Lair, G.J., Gerzabek, M.H. 2009. Rapid Carbon Accretion and Organic Matter Pool 772 Stabilization in Riverine Floodplain Soils. Global Biogeochemical Cycles 23(4).

773 Zhang, H., Schrader, S. 1992. Earthworm Effects of Selected Physical and Chemical Properties of Soil 774 Aggregates. Biology and Fertility of Soils 15: 229 - 234.

775 Zorn, M. I., Van Gestel, C. A. M., Eijsackers, H. 2005. Species-Specific Earthworm Population 776 Responses in Relation to Flooding Dynamics in a Dutch Floodplain Soil. Pedobiologia, 49: 189-198. 


\section{Supplementary Information}

Table SI-1 - The mean, standard deviation, and number of pits in which individuals were present used to calculate the mean, of the abundance of adults $\mathrm{m}^{-2}$ of each of the seven earthworm species found in the crop, margin, and pasture sites. Standard deviation N/A indicates earthworm presence in only one pit across all sampling dates.

\begin{tabular}{|c|c|c|c|c|c|c|}
\hline \multirow[b]{2}{*}{ Species } & \multicolumn{2}{|c|}{ Crop } & \multicolumn{2}{|c|}{ Margin } & \multicolumn{2}{|c|}{ Pasture } \\
\hline & Rarely flooded & $\begin{array}{l}\text { Frequently } \\
\text { flooded }\end{array}$ & Rarely flooded & Frequently flooded & Rarely flooded & Frequently flooded \\
\hline A. chlorotica & $50( \pm 37.98,14)$ & $\begin{array}{c}56.82( \pm 37.23 \\
11)\end{array}$ & $25(\mathrm{~N} / \mathrm{A}, 1)$ & $\begin{array}{c}52.27( \pm 48.03 \\
11)\end{array}$ & $76.19( \pm 48.40,21)$ & $\begin{array}{c}151.52( \pm 96.61 \\
33)\end{array}$ \\
\hline A. caliginosa & $41.67( \pm 20.41,6)$ & $25( \pm 0,2)$ & $53.57( \pm 22.49,7)$ & $37.5( \pm 13.69,6)$ & $31.67( \pm 19.97 .15)$ & $50.93( \pm 47.27,27)$ \\
\hline A. rosea & $33.33( \pm 14.43,3)$ & $25(\mathrm{~N} / \mathrm{A}, 1)$ & $25( \pm 0,2)$ & $25( \pm 0,2)$ & $25( \pm 0,9)$ & $34.38( \pm 18.60,8)$ \\
\hline L. castaneus & & & $25(\mathrm{~N} / \mathrm{A}, 1)$ & $43.75( \pm 23.94,4)$ & $50(\mathrm{~N} / \mathrm{A}, 1)$ & $31.25( \pm 12.25,4)$ \\
\hline L. rubellus & & $25(\mathrm{~N} / \mathrm{A}, 1)$ & $32.14( \pm 12.20 .7)$ & $29.17( \pm 10.21,6)$ & $29.17( \pm 10.21,6)$ & $32.14( \pm 11.72,14)$ \\
\hline L. terrestris & $25(0,2)$ & & $25(\mathrm{~N} / \mathrm{A}, 1)$ & $25(\mathrm{~N} / \mathrm{A}, 1)$ & $25( \pm 0,3)$ & $37.50( \pm 17.68,2)$ \\
\hline
\end{tabular}


Table SI - 2. The mean, standard deviations, and $\mathbf{n}$ of the average biomass ( $\mathrm{g}$ ) of individuals of each of the seven earthworm species found in the crop, margin, and pasture sites. Empty cells showed no presence of earthworm individuals. Standard deviation N/A indicates only one earthworm individual.

\begin{tabular}{|c|c|c|c|c|c|c|}
\hline \multirow[b]{2}{*}{ Species } & \multicolumn{2}{|c|}{ Crop } & \multicolumn{2}{|c|}{ Margin } & \multicolumn{2}{|c|}{ Pasture } \\
\hline & Rarely flooded & $\begin{array}{c}\text { Frequently } \\
\text { flooded }\end{array}$ & Rarely flooded & Frequently flooded & Rarely flooded & Frequently flooded \\
\hline A. chlorotica & $0.32( \pm 0.12,28)$ & $0.34( \pm 0.12,25)$ & $0.20(\mathrm{~N} / \mathrm{A}, 1)$ & $0.21( \pm 0.04,23)$ & $0.26( \pm 0.08,177)$ & $0.22( \pm 0.04,87)$ \\
\hline A. caliginosa & $0.32( \pm 0.16,10)$ & $0.35( \pm 0.14,2)$ & $0.38( \pm 0.17,15)$ & $0.36( \pm 0.15,9)$ & $0.39( \pm 0.18,34)$ & $0.43( \pm 0.14,40)$ \\
\hline A. rosea & $0.24( \pm 0.10,4)$ & $0.21(\mathrm{~N} / \mathrm{A}, 1)$ & $0.15( \pm 0.08,2)$ & $0.20( \pm 0.05,4)$ & $0.21( \pm 0.06,9)$ & $0.23( \pm 0.05,11)$ \\
\hline L. castaneus & & & $0.15(\mathrm{~N} / \mathrm{A}, 1)$ & $0.11( \pm 0.03,7)$ & $0.14( \pm 0.07,3)$ & $0.15( \pm 0.07,4)$ \\
\hline L. rubellus & & $0.69(\mathrm{~N} / \mathrm{A}, 1)$ & $0.18( \pm 0.03,9)$ & $0.28( \pm 0.19,7)$ & $0.54( \pm 0.25,16)$ & $0.41( \pm 0.17,9)$ \\
\hline L. terrestris & $3.15( \pm 0.60,2)$ & & $0.32(\mathrm{~N} / \mathrm{A}, 1)$ & $0.16(\mathrm{~N} / \mathrm{A}, 1)$ & $2.93( \pm 2.09,3)$ & $1.04( \pm 1.16,3)$ \\
\hline
\end{tabular}


Table SI - 3. The mean and standard deviations of Shannon Diversity Index values for the earthworm populations across the different combinations of land use and flooding frequency, and the mean and standard deviations of the percentage of individuals retrieved by allyl isothicyanate (AITC) poured into the excavated pit.

\begin{tabular}{|c|c|c|c|}
\hline Flooding frequency & Crop & Margin & Pasture \\
\hline \multicolumn{4}{|c|}{ Total number of individuals recorded } \\
\hline Rarely flooded & 267 & 157 & 753 \\
\hline Frequently flooded & 106 & 335 & 1025 \\
\hline \multicolumn{4}{|c|}{ Shannon Diversity index values } \\
\hline Rarely flooded & $1.12( \pm 0.46)$ & $0.77( \pm 0.60)$ & $1.41( \pm 0.32)$ \\
\hline Frequently flooded & $0.61( \pm 0.44)$ & $1.24( \pm 0.42)$ & $1.18( \pm 0.54)$ \\
\hline \multicolumn{4}{|c|}{ Percentage of individuals retrieved with allyl isothiocyanate } \\
\hline Rarely flooded & $5.11 \%( \pm 2.30)$ & $11.54 \%( \pm 14.12)$ & $4.14 \%( \pm 1.37)$ \\
\hline Frequently flooded & $2.54 \%( \pm 4.21)$ & $1.41 \%( \pm 1.67)$ & $1.79 \%( \pm 0.64)$ \\
\hline
\end{tabular}

